\title{
Chemical and Electrochemical Combined Processes to Treat Sanitary Landfill Leachates
}

\author{
A. Fernandes, ${ }^{*}$ N. Afonso, J. Coelho, M.J. Pacheco, L. Ciríaco and A. Lopes \\ FibEnTech/MTP Unit and Department of Chemistry, University of Beira Interior, \\ 6201-001 Covilhã, Portugal
}

\begin{abstract}
The application of combined chemical coagulation and electrochemical oxidation processes to treat a leachate from an intermunicipal sanitary landfill was evaluated. Chemical coagulation (CC) experiments were performed with lime $\left(\mathrm{Ca}(\mathrm{OH})_{2}\right)$, and the influence of the lime concentration, stirring speed and assay duration were studied. In the electrochemical oxidation (EO) assays, a boron-doped diamond anode was used, and two applied current intensities were tested. It was also evaluated the influence of the lime concentration used in the CC pre-treatment on the EO performance. In the CC assays, the highest COD removals were obtained for lime concentrations of 20 and $25 \mathrm{~g}$ $\mathrm{L}^{-1}$, at $100 \mathrm{rpm}$ stirring speed, during $2 \mathrm{~h}$. In the $\mathrm{CC}+\mathrm{EO}$ combined treatment the highest removals were obtained at the applied current intensity of $0.6 \mathrm{~A}$, being the influence of the lime concentration used in the pre-treatment almost insignificant. The highest current efficiency was obtained for the combined treatment with EO assays performed at $0.4 \mathrm{~A}$.
\end{abstract}

Keywords: landfill leachate; chemical coagulation; lime concentration; electrochemical treatments; electrochemical oxidation; BDD.

\section{Introduction}

Huge amounts of solid wastes are being produced daily and the simplest procedure for their discharge, with low cost, is the deposition on sanitary landfills [1]. However, as a result of rainwater percolation through the wastes, a very complex effluent is produced, usually known as sanitary landfill leachate. This leachate composition is very complex and it may contain all type of organic and inorganic compounds, some of them refractory and toxic, and heavy metals

\footnotetext{
* Corresponding author. E-mail address: annabelf@ubi.pt.
} 
$[1,2]$. Besides the organic matter, ammonia nitrogen is of great environmental concern in landfill leachates [3]. It is released from wastes mainly due to the decomposition of proteins and has been found in leachates at a concentration range from 0.2 to $13000 \mathrm{mg} \mathrm{L}^{-1}$ [4].

Nowadays, biological reactors, with nitrification/denitrification steps, followed by membrane technologies, are commonly used to treat leachates. However, due to the variability in the quality and quantity of the leachate throughout the life span of the treatment plant, these conventional treatments may become ineffective. Thus, it is very important to apply reliable and effective treatment technologies, capable of deal with such complex effluents.

Efficient methods for sanitary landfill leachates remediation based on electrochemical technologies are being developed. Among them, electrochemical oxidation (EO) is the most popular electrochemical procedure for removing organic pollutants from wastewaters, being boron-doped diamond (BDD) the most intensively studied anode material [5]. There are several papers describing the application of EO in sanitary landfill leachates, with promising results [3,610]. In fact, this treatment method has shown high potential to treat efficiently sanitary landfill leachates, although the high energetic costs are pointed as the main drawback to its full-scale implementation. EO integration with other treatment methods can be a possible solution to overcome this drawback.

There are several reports describing the application of combined methods involving EO to treat sanitary landfill leachates [11-23]. A simple and economic process, widely used in wastewater treatment plants, is the chemical coagulation (CC). This process has shown to be efficient in the treatment of sanitary landfill leachates and has been widely used as a pre-treatment, prior to biological or reverse osmosis steps, or as a final polishing treatment step, in order to remove non-biodegradable organic matter [4]. The efficiency of the CC process depends on several factors, such as the nature and dosages of the coagulant, the characteristics of the leachate, the use of the process as a pre-treatment or posttreatment [4].

Several authors refer lime as the most used reagent in $\mathrm{CC}$ processes, being the amount required to treat sanitary landfill leachates between 1 to $15 \mathrm{~g} \mathrm{~L}^{-1}$ [24-27]. The main advantages of using lime in the CC process include its low cost, its availability in many countries and the fact that it does not contribute to increase salinity, as happens when aluminum or iron salts are employed.

According to Renou et al. [28], CC with lime acts preferentially in organic compounds of high molecular weight, such as humic acids present in stabilized leachates. Also, the CC treatment with lime eliminates most of the organic macromolecules in the first moments of the reaction, being almost $91 \%$ of the organic matter removed during the first $30 \mathrm{~s}$ and more than $99 \%$ removed at the end of a rapid mixing (5 min) [29].

The aim of this work was to evaluate the application of CC and EO as a combined treatment for a leachate from an intermunicipal sanitary landfill. The $\mathrm{CC}$ with lime was used as a first step, in order to remove colloidal and suspended particles, and it was followed by EO to eliminate the remaining dissolved persistent organic compounds. In the $\mathrm{CC}$ experiments, different added lime 
concentrations, stirring speed and assay durations were tested, in order to study their influence on the removal of the organic matter. In the EO assays, performed with a BDD anode, the influence of the applied current density and of the CC pre-treatment lime concentration, was studied.

\section{Materials and methods}

\section{Leachate samples}

The leachate samples used in this study were collected at a Portuguese intermunicipal sanitary landfill site, with an area of $1 \mathrm{~km}^{2}$ divided in 7 cells, being 6 of them sealed since 2012. Approximately $250 \mathrm{~m}^{3}$ of leachate are produced daily at this landfill facility (average value). Samples were collected in the stabilization lagoon, before being submitted to any treatment, and kept refrigerated, in order to maintain its initial characteristics. Samples characterization is presented in Table 1.

Table 1. Physicochemical characteristics of the leachate samples.

\begin{tabular}{ll}
\hline Parameter & Mean value $\left( \pm \mathrm{SD}^{*}\right)$ \\
\hline $\mathrm{COD} / \mathrm{g} \mathrm{L}^{-1}$ & $4.0 \pm 0.3$ \\
$\mathrm{BOD}_{5} / \mathrm{g} \mathrm{L}^{-1}$ & $1.23 \pm 0.07$ \\
$\mathrm{BOD}_{5} / \mathrm{COD}^{-1}$ & $0.31 \pm 0.04$ \\
$\mathrm{DOC} / \mathrm{g} \mathrm{L}^{-1}$ & $1.36 \pm 0.09$ \\
$\mathrm{DIC} / \mathrm{g} \mathrm{L}^{-1}$ & $1.22 \pm 0.04$ \\
$\mathrm{TN} / \mathrm{g} \mathrm{L}^{-1}$ & $1.34 \pm 0.05$ \\
$\mathrm{TKN} / \mathrm{g} \mathrm{L}^{-1}$ & $1.18 \pm 0.05$ \\
$\mathrm{TAN} / \mathrm{g} \mathrm{L}^{-1}$ & $1.02 \pm 0.02$ \\
$\mathrm{pH}$ & $8.7 \pm 0.1$ \\
$\mathrm{Conductivity} \mathrm{/} \mathrm{mS} \mathrm{cm}$ & $13.8 \pm 0.6$ \\
\hline \multicolumn{2}{c}{$* \mathrm{SD}-$ Standard deviation }
\end{tabular}

\section{Analytical determinations}

Degradation tests were followed by chemical oxygen demand (COD), biochemical oxygen demand (BOD5), dissolved organic carbon (DOC), dissolved inorganic carbon (DIC), total nitrogen (TN), total ammonia nitrogen (TAN) and total Kjeldahl nitrogen (TKN), which were performed according to standard procedures [30]. The COD determinations were made using the closed reflux titrimetric method. The $\mathrm{BOD}_{5}$ was evaluated by determining the oxygen consumption after 5 days of incubation. The DOC, DIC and TN were measured in a Shimadzu TOC- $\mathrm{V}_{\mathrm{CPH}}$ analyzer combined with a TNM-1 unit. Before DOC, DIC and TN determinations, samples were filtered through $1.2 \mu \mathrm{m}$ glass microfiber filters. The TAN and TKN were determined using a Kjeldatherm block-digestion-system and a Vapodest 20s distillation system, both from Gerhardt. The pH was measured using a HANNA pH meter (HI 931400). The conductivity was determined using a Mettler Toledo conductivity meter (SevenEasy S30K). 


\section{Chemical coagulation and electrochemical oxidation assays}

The CC experiments were performed in a Jar tester equipment (Lovibond, ET 730 , portable floc tester), using $0.5 \mathrm{~L}$ of leachate. With the aim of optimizing experimental conditions, a first set of assays was performed, where the added lime concentration was $15 \mathrm{~g} \mathrm{~L}^{-1}$ and the stirring speed and assay duration were varied between 50-200 rpm and 1-4 h, respectively.

Based on the results obtained in this first set of assays, a second set of CC assays was performed, where different lime concentrations between 10 and $25 \mathrm{~g} \mathrm{~L}^{-1}$ were tested, applying a stirring speed and assay duration of $100 \mathrm{rpm}$ and $2.5 \mathrm{~h}$, respectively.

All the $\mathrm{CC}$ experiments were conducted at room temperature $\left(22-25^{\circ} \mathrm{C}\right)$. After the $\mathrm{CC}$ treatment, the samples were centrifuged in a high frequency induction motor centrifuge (Meditronic BL-S), at $5000 \mathrm{rpm}$ during $5 \mathrm{~min}$, and the supernatant liquid was collected for the analytical determinations. For the first set of assays, only COD was determined.

In the combined treatment of $\mathrm{CC}+\mathrm{EO}$, the $\mathrm{CC}$ was performed using 20 and $25 \mathrm{~g}$ $\mathrm{L}^{-1}$ of lime and, after that, the centrifuged samples were subjected to the EO treatment.

The EO experiments were conducted in batch mode with stirring (100 rpm), during $6 \mathrm{~h}$, at room temperature $\left(22-25^{\circ} \mathrm{C}\right)$ and using $200 \mathrm{~mL}$ of the coagulated effluent. A BDD anode and a stainless steel cathode, both with an area of $10 \mathrm{~cm}^{2}$, were used. The applied current intensities evaluated were 0.4 and $0.6 \mathrm{~A}$. In the electrochemical experiments it was used a DC power supply GW, Lab DC, model GPS-3030D (0-30 V, 0-3 A).

Both $\mathrm{CC}$ and EO assays were performed, at least, in duplicate, and the values presented for the analytical parameters used to follow the assays are mean values.

\section{Results and discussion}

Fig. 1 presents the COD removals obtained for the chemical coagulation assays performed with different stirring speed and assay duration, at a lime concentration of $15 \mathrm{~g} \mathrm{~L}^{-1}$. From the obtained results, it can be seen that stirring speed of $100 \mathrm{rpm}$ promoted higher COD removals than stirring speed of $50 \mathrm{rpm}$. This can be due to the fact that when stirring is slow, lime stays deposited in the bottom of the beaker, and does not react efficiently with the leachate. However, when stirring speed was increased to $200 \mathrm{rpm}$, except for the assay with $1 \mathrm{~h}$ duration, a slight decrease in COD removals was observed when compared with the assays performed at $100 \mathrm{rpm}$, probably because excessive stirring inhibits the hydroxides action, being the formed flocks smaller and with less tendency to precipitate.

Regarding to assays duration, it can be seen from Fig. 1 that, around $2.5 \mathrm{~h}$, there is a stabilization in the COD removal and longer assay duration does not lead to higher COD removal. Based on these results, to perform the CC assays the most suitable conditions were a duration of $2.5 \mathrm{~h}$ with a stirring speed of $100 \mathrm{rpm}$. Thus, in the subsequent assays performed to study the influence of the lime concentration, experiments were conducted at those experimental conditions. 
Inset of Fig. 1 presents the COD removals obtained in the assays performed at $100 \mathrm{rpm}$ stirring speed, during $2.5 \mathrm{~h}$, with lime concentration varying from 10 to $25 \mathrm{~g} \mathrm{~L}^{-1}$. It can be observed that the best COD removals were obtained at 20 and $25 \mathrm{~g} \mathrm{~L}^{-1}$, with only a small difference between the removals obtained with these lime concentrations. Table 2 presents the results obtained for the CC assays performed with different lime concentrations. As it can be seen, COD removal increased with the amount of lime added, achieving a COD removal of $43 \%$ when the lime concentration was $25 \mathrm{~g} \mathrm{~L}^{-1}$. DOC removal was low when compared with DIC removal and presented its high values at lime concentrations of 20 and $25 \mathrm{~g} \mathrm{~L}^{-1}$. DIC removal was above $90 \%$ for all the lime concentrations tested, with no significant differences between them. All forms of nitrogen measured presented low removals, especially TAN, being the highest removal values obtained for lime concentrations of 20 and $25 \mathrm{~g} \mathrm{~L}^{-1}$. Biodegradability index, measured by the ratio $\mathrm{BOD}_{5} / \mathrm{COD}$, largely increased when compared to the initial sample, although this increase decreased with the amount of lime added. Thus, the best experimental conditions chosen to perform the CC pretreatment were: 20 and $25 \mathrm{~g} \mathrm{~L}^{-1}$ lime concentration; $2.5 \mathrm{~h}$ assay duration; stirring speed of $100 \mathrm{rpm}$. These optimized lime concentrations are higher than those usually found in literature [24-27]. This can be due to the different characteristics of the sanitary landfill leachate used.

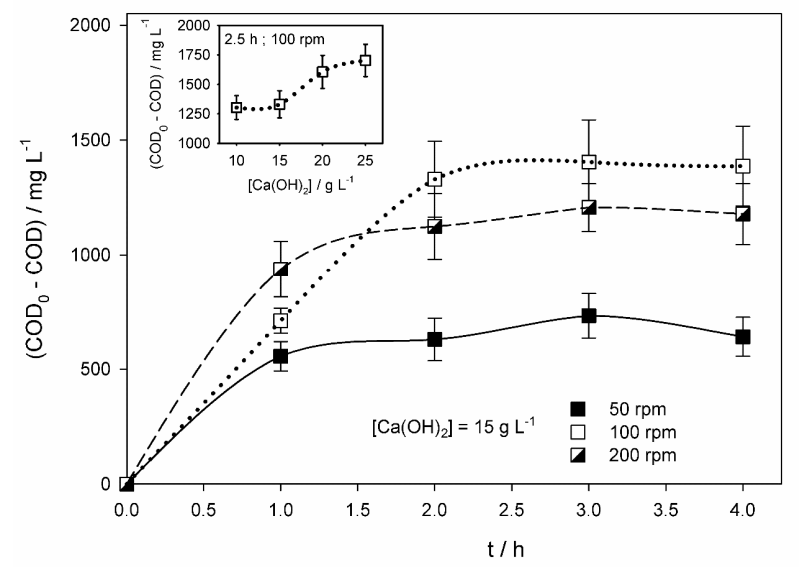

Figure 1. Experimental results for the COD removal in the CC assays performed with different stirring speed and assay duration, at a lime concentration of $15 \mathrm{~g} \mathrm{~L}^{-1}$, and (inset) different lime concentration, at a stirring speed of $100 \mathrm{rpm}$ during $2.5 \mathrm{~h}$.

The results of the EO experiments performed with samples pre-treated with CC are shown in Fig. 2 and in Table 3. From Fig. 2, it can be seen that COD removal is more influenced by the current intensity applied in the EO process than by the lime concentration added in the CC pre-treatment.

Fig. 2 also includes the COD theoretical decay, calculated for the two current intensities, using Eq. (1), where $\mathrm{COD}_{0}$ and $\mathrm{COD}_{\mathrm{t}}$ are the initial $\mathrm{COD}$ and COD at time $\mathrm{t}$, in $\mathrm{mg} \mathrm{L}^{-1}$, $\mathrm{I}$ is the current intensity, in $\mathrm{A}, \mathrm{F}$ is the Faraday constant, 96485 $\mathrm{C} \mathrm{mol}^{-1}, \mathrm{~V}$ is the solution volume, in $\mathrm{m}^{3}$, and $\mathrm{t}$ is the time, in $\mathrm{s}$. From the theoretical lines, it can be inferred that the current efficiency decreases with the increase of current intensity, since the deviation between theoretical and 
experimental curves is higher for the assay run at the highest applied current intensity.

$$
\mathrm{COD}_{\mathrm{t}}=\mathrm{COD}_{0}-\frac{\mathrm{I}}{4 \mathrm{FV}} \mathrm{t}
$$

Table 2. Experimental results for the chemical coagulation assays performed with different lime concentrations, stirring speed of $100 \mathrm{rpm}$ and 2.5 hours duration.

\begin{tabular}{|c|c|c|c|c|c|}
\hline & \multirow{2}{*}{ Parameter } & \multicolumn{4}{|c|}{ Lime concentration / $\mathrm{g} \mathrm{L}^{-1}$} \\
\hline & & 10 & 15 & 20 & 25 \\
\hline \multirow{7}{*}{$\begin{array}{l}\text { Removal } \\
/ \mathrm{g} \mathrm{L}^{-1}\end{array}$} & COD & $1.3 \pm 0.1$ & $1.3 \pm 0.2$ & $1.6 \pm 0.2$ & $1.7 \pm 0.2$ \\
\hline & $\mathrm{BOD}_{5}$ & $0.70 \pm 0.05$ & $0.67 \pm 0.05$ & $0.65 \pm 0.07$ & $0.65 \pm 0.02$ \\
\hline & DOC & $0.30 \pm 0.04$ & $0.39 \pm 0.03$ & $0.46 \pm 0.04$ & $0.45 \pm 0.04$ \\
\hline & DIC & $1.11 \pm 0.02$ & $1.12 \pm 0.03$ & $1.12 \pm 0.02$ & $1.12 \pm 0.05$ \\
\hline & TN & $0.18 \pm 0.03$ & $0.196 \pm 0.001$ & $0.19 \pm 0.02$ & $0.21 \pm 0.03$ \\
\hline & TKN & $0.118 \pm 0.001$ & $0.13 \pm 0.03$ & $0.15 \pm 0.04$ & $0.15 \pm 0.05$ \\
\hline & TAN & $0.03 \pm 0.03$ & $0.03 \pm 0.01$ & $0.05 \pm 0.02$ & $0.038 \pm 0.005$ \\
\hline \multirow{3}{*}{$\begin{array}{c}\text { Final } \\
\text { values }\end{array}$} & $\mathrm{pH}$ & $12.9 \pm 0.1$ & $13.1 \pm 0.1$ & $13.2 \pm 0.1$ & $13.2 \pm 0.2$ \\
\hline & Cond. / mS & $15.5 \pm 0.8$ & $17.8 \pm 0.1$ & $18.9 \pm 0.6$ & $19.5 \pm 0.8$ \\
\hline & $\mathrm{BOD}_{5} / \mathrm{COD}$ & 0.54 & 0.50 & 0.41 & 0.38 \\
\hline
\end{tabular}

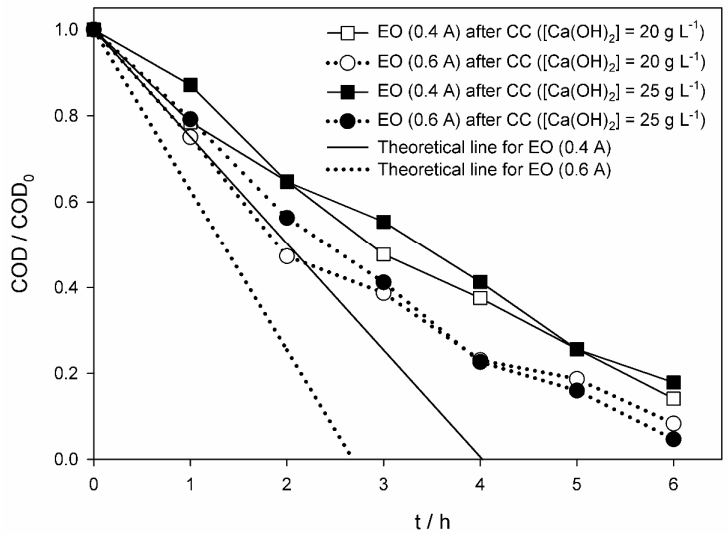

Figure 2. Experimental and theoretical relative COD as a function of time for the EO assays performed at 0.4 and $0.6 \mathrm{~A}$ with leachate samples submitted to a CC pretreatment performed at different coagulant concentrations (20 and $25 \mathrm{~g} \mathrm{~L}^{-1}$ of lime).

DOC and TN removals present a similar behaviour to that of COD (Table 3). Regarding TKN and TAN parameters, they present higher removals than TN, indicating that nitrates are still present in solution at the end of the assays. For all the conditions tested, TKN and TAN removals in the combined treatment were around $100 \%$.

During the EO process, the $\mathrm{pH}$ returned to its original value and the conductivity values dropped drastically, which can be attributed to the formation of carboxylic acids during the oxidation of the organic matter, and to the deposition on the cathode surface of reduced ionic species, respectively. 
Table 3. Experimental results for the EO assays performed at different current intensities with samples from the CC pre-treatments, performed with 20 and $25 \mathrm{~g} \mathrm{~L}^{-1}$ lime concentration.

\begin{tabular}{|c|c|c|c|c|c|}
\hline \multirow{2}{*}{\multicolumn{2}{|c|}{$\begin{array}{c}\text { Chemical coagulation } \\
\text { pre-treatment }\end{array}$}} & \multicolumn{4}{|c|}{ Lime concentration / g L $\mathbf{L}^{-1}$} \\
\hline & & & & & 5 \\
\hline \multirow{2}{*}{\multicolumn{2}{|c|}{ Parameter }} & \multicolumn{4}{|c|}{ Applied current intensity / A } \\
\hline & & 0.4 & 0.6 & 0.4 & 0.6 \\
\hline \multirow{5}{*}{$\begin{array}{l}\text { Removal } \\
/ \mathrm{g} \mathrm{L}^{-1}\end{array}$} & $\mathrm{COD}$ & $2.0 \pm 0.1$ & $2.1 \pm 0.1$ & $1.97 \pm 0.08$ & $2.19 \pm 0.09$ \\
\hline & DOC & $0.55 \pm 0.04$ & $0.70 \pm 0.05$ & $0.62 \pm 0.05$ & $0.70 \pm 0.07$ \\
\hline & $\mathrm{TN}$ & $0.71 \pm 0.05$ & $0.79 \pm 0.05$ & $0.75 \pm 0.04$ & $0.77 \pm 0.04$ \\
\hline & $\mathrm{TKN}$ & $0.83 \pm 0.04$ & $1.04 \pm 0.05$ & $0.87 \pm 0.04$ & $0.87 \pm 0.03$ \\
\hline & TAN & $0.77 \pm 0.02$ & $0.94 \pm 0.03$ & $0.82 \pm 0.04$ & $0.87 \pm 0.03$ \\
\hline \multirow{2}{*}{$\begin{array}{l}\text { Final } \\
\text { values }\end{array}$} & $\mathrm{pH}$ & $8.3 \pm 0.2$ & $8.4 \pm 0.1$ & $8.5 \pm 0.1$ & $8.4 \pm 0.2$ \\
\hline & Conductivity $/ \mathrm{mS} \mathrm{cm}^{-1}$ & $6.9 \pm 0.5$ & $7.2 \pm 0.4$ & $8.7 \pm 0.7$ & $8.7 \pm 0.6$ \\
\hline
\end{tabular}

\section{Conclusions}

According to the obtained results, the application of combined chemical coagulation and electrochemical oxidation seems feasible for the treatment of leachates from sanitary landfills. The addition of lime promotes good COD removals, although the removals of the different nitrogen forms are small, particularly for the total ammonia nitrogen. Also, an increase in the biodegradability is noticed by the addition of lime.

EO treatment, using pre-treated leachate by $\mathrm{CC}$ with lime, results in high COD removals and complete TKN and TAN removals.

Attending to the lime consumption and the energy costs with stirring, during the $\mathrm{CC}$ pre-treatment, and with the $\mathrm{EO}$ process, the most favorable conditions found for the combined treatment were $\mathrm{CC}$ with $20 \mathrm{~g} \mathrm{~L}^{-1}$ of lime at $100 \mathrm{rpm}$ stirring speed, during $2.5 \mathrm{~h}$, followed by EO at $0.4 \mathrm{~A}$, during $6 \mathrm{~h}$.

\section{Acknowledgements}

The authors gratefully acknowledge the financial support received from FCT, for the funding of the FibEnTech Research Unit, through "Financiamento agregado para o biénio 2015-2016", project UID/Multi/00195/2013, and for the grant awarded to A. Fernandes, SFRH/BPD/103615/2014.

\section{References}

1. Eggen T, Moeder M, Arukwe A. Sci Total Environ. 2010;408:5147-5157.

2. Öman CB, Junestedt C. Waste Manage. 2008;28:1876-1891.

3. Deng Y, Englehardt JD. Waste Manage. 2007;27:380-388.

4. Renou S, Givaudan JG, Poulain S, et al. J Hazard Mater. 2008;150:468-493.

5. Martínez-Huitle CA, Brillas E. Appl Catal B: Environ. 2009;87:105-145.

6. Cossu R, Polcaro A, Lavagnolo M, et al. Environ Sci Technol. 1998;32:3570-3573.

7. Cabeza A, Urtiaga A, Ortiz I. Ind Eng Chem Res. 2007;46:1439-1446. 
8. Anglada A, Urtiaga A, Ortiz I. J Hazard Mater. 2010;181:729-735.

9. Fernandes A, Pacheco MJ, Ciríaco L, et al. J Hazard Mater. 2012;199200:82-87.

10. Fernandes A, Pacheco MJ, Ciríaco L, et al. Appl Catal B: Environ. 2015;176:183-200.

11. Wang P, Lau IWC, Fang HHP. Environ Technol. 2001;22:373-381.

12. Ihara I, Kanamura K, Shimada E, et al. IEEE Transactions on Applied Superconductivity 2004;14:1558-1560.

13. Lei Y, Shen Z, Huang R, et al. Water Res. 2007;41:2417-2426.

14. Feki F, Aloui F, Feki M, et al. Chemosphere 2009;75:256-260.

15. Papastavrou C, Mantzavinos D, Diamadopoulos E. Environ Technol. 2009;30:1547-1553.

16. Urtiaga A, Rueda A, Anglada A, et al. J Hazard Mater. 2009;166:15301534.

17. Zhao X, Qu J, Liu H, et al. Bioresour. Technol. 2010;101:865-869.

18. Norma D, Fernandes A, Pacheco MJ, et al. Port Electrochim Acta. 2012;30:221-234.

19. Norma D, Fernandes A, Ciríaco L, et al. Port Electrochim Acta. 2012;30:281-294.

20. Orkun MO, Kuleyin A. Environ Prog Sust Energy. 2012;31:59-67.

21. Garaj-Vrhovac V, Orescanin V, Gajski G, et al. Chemosphere. 2013;93:939-945.

22. Xiao S, Peng J, Song Y, et al. Sep Purif Technol. 2013;117:24-29.

23. Fernandes A, Spranger P, Fonseca AD, et al. Appl. Catal. B: Environ. 2014;144:514-520.

24. Thornton RJ, Blanc FC. J Environ Eng Div. 1973;99:535-544.

25. Ho S, Boyle CW, Ham RK. Water Pollution Control Federation 1974;46:1776-1791.

26. Keenan JD, Steiner RL, Fungaroli AA. J Environ Eng. 1983;109:13711384.

27. Slater CS, Ahlert, RC, Uchrin CG. Environ Prog. 1983;2:251-256.

28. Renou S, Poulain S, Givaudan JG, et al. J Membr Sci. 2008;313:9-22.

29. Renou S, Poulain S, Givaudan JG, et al. Water Sci Technol. 2009;59:673685.

30. Eaton A, Clesceri L, Rice E, et al. Standard methods for examination of water and wastewater. 21st ed. Washington, DC: American Public Health Association; 2005. 